\title{
INSTITUTT FOR ATOMENERGI, KJELLER
}

$\mathrm{T}$ HE Institutt for Atomenergi, Kjeller, Norway, is an independent foundation governed by a board of six members, consisting of two each appointed by the Norwegian Government, the firm Norsk Hydro, and the Royal Norwegian Council for Scientific and Industrial Research.

The report of the activities of the Institute during $1963 *$ states that special attention was directed to the development of a reactor for marine propulsion. The Rederiatom ship reactor study project, completed at the beginning of 1963 , showed that the direct cycle, boiling light-water type of reactor justified further investigation. The new study project involves the development of a ship reactor for a 65,000-ton bulk carrier. To reduce the capital cost, the machinery has been greatly simplified and carbon steel utilized for the reactor pressure vessel, piping and other structural components. The Swedish A. B. Atomenergi has expressed interest in the project and an agreement has been reached under which the development work is to be carried out at Kjellor as a joint Norwegian-Swedish project. The work is supported by industry and shipping firms in both countries and the budget for the four-year period covered by the agreement is about 2 million dollars, of which Norway and Sweden each contribute 1 million dollars. Corrosion, contamination, reactor physics, hydraulics and control and instrumentation, constitute some of the major problems to be solved. At the end of the project, in 1966, it is expected that the results will enable a decision to be taken on whether the building and initial operation of a nuclearpowered ship are justified.

The operation of the Organization for Economic Cooperation and Development's Halden reactor has mainly been concentrated on investigations of the dynamic behaviour, at power-levels up to $20 \mathrm{MW}$, of boiling-water reactors, and the results of the experiments are being incorporated in a mathematical model describing the behaviour. New in-core instruments for measurements of flow velocities, steam volume and temperature distribution have been developed. On December 20, 1963, steam was delivered for the first time to the Saugbrugsforeningen paper and pulp factory. The original agreement creating the international Halden project expired at the end of 1962 , but the agreement was extended until the summer of 1964. A new agreement for the period 1964-66 was signed in October 1963. This will involve an

\footnotetext{
* Institutt for Atomenergi, Kjeller, Norway. Survey of Actirities 1963
} P1. 29. (Kjeller, Norway: Institutt for Atomenergi, 1964.) expenditure of about 3.6 million dollars and the programme will include long-term irradiation tests of fuel elemonts of simplified design and tests of elements at high specific loads, in addition to various chemical, dynamic and static investigations.

The Nora project, which is a joint undertaking of the Institute and of the International Atomic Energy Agency, provides reliable reactor physies data for water-moderated reactors. The Nora zero-energy reactor at Kjeller, commissioned in 1961, is well suited, because of its flexible design, for such research. The recent programme has comprised extensive measurements on $\mathrm{D}_{2} \mathrm{O} / \mathrm{H}_{2} \mathrm{O}$ moderated systems using the 3 per cent enriched uranium dioxide fuel charge supplied by the U.S. Atomic Energy Commission. The $400 \cdot \mathrm{kW}$ reactor Jeep has continued routine operation throughout the year under review and provided a neutron source for the production of radioisotopes and for neutron physies work. The new research reactor, Jeep Ir, which is being built at Kjeller, is due to come into operation this year, and then will take over the work done by the other reactor. The maximum output is to be $2 \mathrm{MW}$ (thermal) at a maximum thermal neutron flux of $2.7 \times 10^{13}$ neutrons $\mathrm{cm}^{-2} \mathrm{~s}^{-1}$, and the reactor will have 19 fuel elements of 3.5 per cent enriched uranium dioxide in clusters of 11 stringers. The moderator is heavy water.

New methods for inclastic neutron seattering experiments have been tried and investigations on spin waves have shown that polarized neutron beams can be used with advantage. Unpolarized beams have been used for the investigation of excitations in magnetic metals and measurements on iron have shown that the magnetic moments attached to respectively $3 d$ and $4 d$ electrons have opposite orientations. The demand for radioisotopes increased and the total deliveries from Kjeller during 1963 were 3,200 , some 20 per cent greater than the figure for 1962. Methods for labelling biological compounds were developed, and the labelled compounds were widely used in medical investigations.

The Netherlands-Norwegian Reactor School arranged, during the summer of 1963 , a two-week international course on corrosion and water chemistry problems connected with water-cooled power reactors, followed by a course on nuclear physics with thermal neutrons. A nine-week course on reactor engineering fundamentals and a one-week course on the utilization of analogue computers were also held.

S. WeintrovB

\section{EFFECTS OF LIGHTNING ON HYDROMETEORS}

\author{
By DR. GUY G. GOYER \\ National Center for Atmospheric Research, Boulder, Colorado
}

T HROUGH the ages reports have been published on meteorological observations attributed to shock waves or sonic waves transmitted through the air. In the Middle Ages, church bells were often rung to reduce the damage due to heavy storms. During the First and Second World Wars, several reports indicated the occurrence of heavy rains immediately after ferocious artillery battles. To-day explosivo charges are used to generate shock waves in clouds in an effort to reduce crop damage from hail, mostly in Italy, Austria, South Africa and France. Despite the continuous recurrence of such reports in the literature, so far as I know, no fundamental systematic investigation of such effects has been carried out. The development of modern tochnology makes new tools and new methods available for such research. Shock tubes and explosive technology permit the generation of shock waves of known strength and duration applicable to the examination, in the laboratory, of their effect on hydrometeors.

Such laboratory and field experiments would contribute to a better understanding of lightning discharges, considered as shock-wave generators, and of their effects on the life- 